\title{
A krónikus derékfájdalom korszerü diagnosztikája és kezelése a nemzetközi irányelvek tükrében
}

\author{
Forgács-Kristóf Katalin ${ }^{1}$ - Major János dr. ${ }^{2}$ - Ádám Szilvia dr. ${ }^{3}$ \\ ${ }^{1}$ Mentális Egészségtudományok Doktori Iskola, Semmelweis Egyetem, Budapest \\ ${ }^{2}$ Bethesda Gyermekkórház, Fájdalomterápiás Ambulancia, Budapest \\ ${ }^{3}$ Semmelweis Egyetem, Egészségügyi Közszolgálati Kar, Egészségügyi Menedzserképző Központ, Budapest
}

\begin{abstract}
Nemzetközi kutatások szerint a deréktáji fájdalom 2019-ben 568 millió embert érintett világszerte. Magyarországon a lakosság 20\%-a él krónikus derékfájdalommal, ami nemcsak egészségügyi, de szociális és ökonómiai krízist is jelent. A probléma aktualitását jól mutatja az is, hogy a Nemzetközi Fájdalomkutatási Társaság a 2021. évet a derékfájdalomról szóló globális évnek kiáltotta ki. A derékfájdalmak megfelelő kezelése és a krónikussá válás megelőzése tehát kiemelten fontos. Ebben nyújthatnak segítséget az evidenciákon alapuló irányelvek. Magyarországon azonban jelenleg nincs hatályos, egységes irányelv, mely a derékfájdalmakkal, azon belül is a krónikus derékfájdalom kezelésével foglalkozna. A jelen közleményben a krónikus derékfájdalom evidenciákon alapuló diagnosztikai és kezelési lehetőségeinek áttekintését tűztük ki célul. Az irodalomkutatást követően, a jelenleg is hatályos, AGREE II. rendszer szerinti magas minőségű besorolást elérő, krónikus deréktáji fájdalomra vonatkozó, angol nyelvű nemzetközi irányelvek ajánlásainak összehasonlítását végeztük el. Tanulmányunkban hét irányelvet dolgoztunk fel (négy európai, kettő amerikai, egy kanadai), melyek mindegyikében a következő közös ajánlások kerültek megfogalmazásra: a súlyos patológiák kizárása az alarm tünetek alapján, a pszichoszociális tényezők figyelembevétele, a szükségtelen képalkotó vizsgálat visszaszorítása, az elsősorban aktív, nem gyógyszeres terápiák preferálása és a nemszteroid gyulladáscsökkentők körültekintő felírása. Az európai irányelvekben új elemként szerepelt a krónikussá válás korai rizikóbecslése.
\end{abstract}

Orv Hetil. 2021; 162(49): 1951-1961.

Kulcsszavak: krónikus fájdalom, derékfájdalom, irányelv, biopszichoszociális

\section{Diagnostic and treatment recommendations from international guidelines for chronic low back pain}

In 2019, low back pain caused the highest burden globally, among musculoskeletal disorders, affecting 568 million people. According to Hungarian sociodemographic data, $20 \%$ of the Hungarian adults live with chronic low back pain that is a global health priority. Therefore, the International Association for the Study of Pain announced 2021 as the global year about back pain. Evidence-based guidelines about the appropriate treatment of acute low back pain and prevention of chronic low back pain are therefore of paramount importance. However, there are currently no valid, uniform treatment guidelines in Hungary about acute and chronic lower back pain. In this paper, we aimed at summarizing up-to-date, evidence-based diagnostic and treatment recommendations for chronic low back pain. Using a literature review, we identified seven international treatment guidelines (four from Europe, two from the United States and one from Canada) in English for the management of chronic low back pain that were previously assessed by the AGREE II quality assessment tool. We found consistent recommendations in the guidelines such as exclusion of alarm symptoms, assessment of psycho-social factors, reduction of unnecessary imaging, initialization of primarily active, non-pharmacological therapies, and careful and cautious prescription of non-steroidal anti-inflammatory medications. A new recommendation in the European guidelines is the early risk assessment of low back pain becoming chronic.

Keywords: chronic pain, low back pain, guideline, bio-psycho-social

Forgács-Kristóf K, Major J, Ádám Sz. [Diagnostic and treatment recommendations from international guidelines for chronic low back pain]. Orv Hetil. 2021; 162(49): 1951-1961.

(Beérkezett: 2021. április 9.; elfogadva: 2021. május 16.) 


\section{Rövidítések}

ACP $=($ American College of Physicians $)$ Amerikai Orvosi Kollégium; $\mathrm{ACT}=($ Acceptance and Commitment Therapy) Elfogadás és Elköteleződés Terápia; AGREE = Appraisal of Guidelines for Research \& Evaluation; CBT = (cognitive behavioral therapy) kognitív viselkedésterápia; EMMI = Emberi Erőforrások Minisztériuma; GDMG = (German Disease Management Guideline) Német Betegségkezelési Irányelv; IASP = (International Association for the Study of Pain) Nemzetközi Fájdalomkutatási Társaság; KCE = (Belgian Health Care Knowledge Centre) Belga Egészségügyi Tudásközpont; NICE = (National Institute for Health and Care Excellence) Az Egészség és Klinikai Kiválóság Nemzeti Intézete (Egyesült Királyság); NSAID $=($ non-steroidal anti-inflammatory drug $)$ nemszteroid gyulladáscsökkentő gyógyszer; PNE = (pain neuroscience education) fájdalomedukáció; SIGN = (Scottish Intercollegiate Guidelines Network) Skót Egyetemi Irányelvek Hálózata; SNRI = (serotonin and noradrenalin reuptake inhibitor) szerotonin-noradrenalin visszavétel gátló; SSRI = (selective serotonin reuptake inhibitor) szelektív szerotoninvisszavétel-gátló; TENS = (transcutaneous electrical nerve stimulation) transzkután elektromos idegstimuláció; TOP = Toward Optimized Practice; VA/DoD $=$ (Department of Veterans Affairs and the U.S. Department of Defense) az USA Veteránügyi Minisztériuma és Védelmi Minisztériuma

Európában minden ötödik felnőtt krónikus mozgásszervi fájdalommal él, amely nemcsak a testi funkciókra, de a szociális interakciókban való részvételre, valamint a pszichés egészség fenntartására is kedvezőtlen hatással van $[1,2]$. A panaszok fennállásának ideje alapján definíció szerint (nem tumoros fájdalom esetén) krónikusnak nevezzük a legalább három hónapja fennálló vagy visszatérő fájdalmat. A mozgásszervi megbetegedések globális prevalenciáját tekintve a deréktáji fájdalom előfordulása a leggyakoribb, mely 2019-ben világszerte 568 millió embert érintett [3]. Magyarországon a lakosság 20\%-a (a férfiak 17\%-a, a nők 22\%-a) él krónikus hát- és derékfájdalommal [4]. Horváth és mtsai 2006. évi, 10 ezer fós magyar mintán végzett reprezentatív vizsgálatában a megkérdezettek 44,1\%-a jelzett aktuálisan is fennálló derékfájdalmat, s közülük $60 \%$-nak ez visszatérő panasz volt [5]. Lokalizáció szerint deréktáji fájdalomnak az alsó bordavonaltól a farpofákig terjedő területen megjelenő, esetenként az egyik vagy mindkét lábba sugárzó fájdalmat tekintjük [6]. A krónikus fájdalom ugyanakkor a fájdalom időbeliségén túlmutató önálló kórkép, amely az idegrendszer neuroplasztikus elváltozásaival jár; kialakulásában és fenntartásában biológiai, pszichés és szociális tényezők egyaránt szerepet játszanak, amire a Nemzetközi Fájdalomkutatási Társaság (IASP) legújabb definíciója is kitér [7].

A hazai és nemzetközi epidemiológiai adatok mellett a probléma aktualitását és fontosságát az is alátámasztja, hogy az IASP a derékfájdalomról szóló globális évnek nyilvánította a 2021-es évet. Ennek oka, hogy a számtalan invazív és noninvazív terápia ellenére a derékfájdalom 1990 óta vezető helyen áll, s folyamatosan növekvő ten- denciát mutat az életviteli korlátozottsággal járó betegségek listáján [8]. Az IASP-munkacsoport célja a kampánnyal az, hogy felhívja a figyelmet a derékfájdalom okozta, egyre növekvő globális teherre, és széles körben megismertesse mind a páciensekkel, mind pedig a szakemberekkel az evidenciákon alapuló prevenciós és kezelési lehetőségeket [9].

A probléma nagyságára tekintettel elengedhetetlen a hatékony megelőzés és kezelés, így a bizonyítékokon (evidenciákon) alapuló szakmai irányelvek folyamatos követése azon egészségügyi szakemberek részéről, akik az érintett betegpopulációt kezelik. A jelenleg rendelkezésre álló evidenciák és a klinikai gyakorlat között sokszor széles a szakadék [10]. A megújuló szakmai ajánlások ismerete és alkalmazása azonban elősegítheti a bizonyítékokon alapuló orvoslás megvalósulását, így javítva a páciensek gyógyulási lehetőségeit és az egészségügy hatékonyságát.

Az Emberi Erőforrások Minisztériumának (EMMI) definíciója szerint „az egészségügyi szakmai irányelv olyan szisztematikusan kifejlesztett ajánlássorozat, amely meghatározott ellátási körülmények között az ellátandók jól körülhatárolt körére vonatkozik, ajánlásai jól azonosíthatók, tudományos bizonyítékokra, illetve valamennyi érintett szakterület szakértőinek véleményére támaszkodva, a betegek szempontjainak figyelembevételével az ellátók és ellátandók adott egészségügyi ellátással kapcsolatos megfelelő döntéseit segíti elő" (18/2013. (III. 5.) EMMI rendelet, 1. $\$$ g) [11]. Az egészségügyi szakmai irányelveket a megjelenést követő 3 . évben felül kell bírálni [12]. Magyarországon jelenleg egy irányelv van érvényben, mely az akut deréktáji fájdalom gyógyszeres kezelésével foglalkozik, ám nem áll rendelkezésre olyan, hatályban lévő szakmai irányelv, amely a krónikus derékfájdalom diagnosztikájára és multidiszciplináris kezelésére is vonatkozna [13].

\section{Célkitüzés és módszer}

A tanulmány célja megismertetni a derékfájdalom kezelését célzó legfrissebb nemzetközi irányelvek hasonlóságait és különbségeit, különös tekintettel a krónikus derékfájdalom gyógyszeres és nem gyógyszeres kezelési lehetôségeire. (A mútéti beavatkozásokra vonatkozó ajánlásokra a jelen tanulmány csak az említés szintjén tér ki.) Az irányelvek azonosításához olyan, 2017 óta megjelent, rendszerezett áttekintő vizsgálatokat kerestünk, melyek a deréktáji fájdalommal foglalkozó irányelveket az Appraisal of Guidelines for Research \& Evaluation (AGREE) II. minőség-ellenőrzési rendszer alapján hasonlították össze [14]. Az irodalomkutatást a PubMeden végeztük, az "AGREE II", „low back pain” és „guideline" keresőszavakkal. 9 találatból 5 olyan, rendszerezett áttekintő tanulmányt találtunk, mely a kutatási célunknak megfelelt [15-19]. Az ismétlődések eltávolítása után összesen 45 irányelv adatait vizsgáltuk át, melyekből tanulmányunkba azokat az irányelveket 
választottuk be, melyek megfeleltek az alábbi kritériumoknak:

1) Az irányelv a krónikus, nem specifikus derékfájdalommal élő felnőtt populációra is kiterjed.

2) Ajánlásokat tesz a krónikus, nem specifikus derékfájdalmak vizsgálatára és kezelésére.

3 ) Multidiszciplináris, nem csak egy szakmaspecifikum lehetőségeit tárgyalja.

4) Az irányelvet 2017 után publikálták, és/vagy 2017 óta felülvizsgálták.

5) Utalást tesz arra, hogy az irányelv jelenleg is érvényben van.

6) Angol nyelven elérhető.

7) Legalább egyszer ajánlott/magas minőségú besorolást kapott az AGREE II-es vizsgálatban.

Az irányelvet kizártuk, ha 2017 előtti volt, és azóta nem vizsgálták felül; ha nem vizsgálták az AGREE II. minőség-ellenőrzési rendszer alapján, vagy nem kapott ajánlott/magas minőségü besorolást; ha nem foglalkozik a krónikus derékfájdalommal; ha nem érhető el angol nyelven; ha nem multidiszciplináris; ha nem érvényes a felnőtt populációra. A beválasztási és kizárási kritériumoknak összesen 7 irányelv felelt meg, melyeket tanulmányunkban összehasonlítottunk. Az azonosítási és a beválasztási folyamatokat az 1 . ábra mutatja.

\section{Nemzetközi irányelvek}

A szakmai irányelvek kidolgozása 5 fó lépésre osztható: 1) a témakör azonosítása és azon belül a klinikailag releváns kérdések megfogalmazása; 2) az irányelv kidolgozásában részt vevő szakemberek és érdekelt felek toborzása, csoportokra osztása, a feladatkörök meghatározása; 3 ) a meghatározott kérdésekre vonatkozó szakirodalom szisztematikus áttekintése; 4) ajánlások megfogalmazása az összegyüjtött evidenciák alapján; 5) az irányelv ellenőrzése külső, szakmailag kompetens személyek által [20]. Az irányelvekben fellelhető hasonlóságok és különbségek tehát nagyban függnek a földrajzi helytől, a kidolgozó szakemberek személyétől, a folyamat elején meghatározott klinikai kérdésektől, valamint az azonosított és felhasznált evidenciáktól.

\section{National Institute of Clinical Excellence (NICE)}

Az angol NICE-irányelv 2016-ban jelent meg. Kidolgozásában 15 fő vett részt, köztük 13 egészségügyi szakember (fájdalomspecialista orvos, gyógyszerész, ápoló, fizioterapeuta/gyógytornász, pszichiáter, háziorvos,

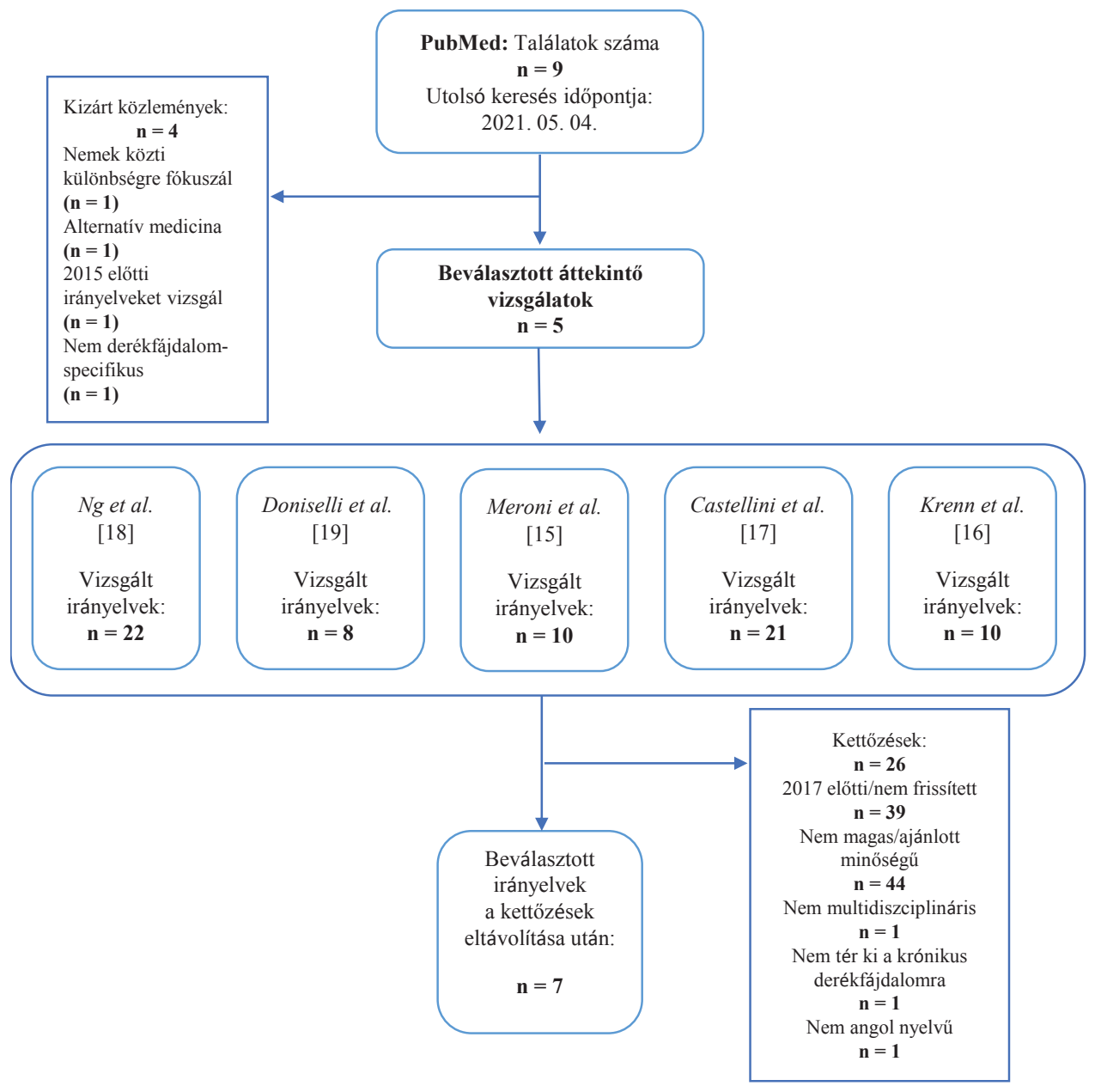


pszichológus, reumatológus) és 2 laikus. A dokumentumban 46 ajánlás található. Az irányelv aktualizált, felülvizsgált változata 2020. szeptember 22-én jelent meg, melyhez a szakirodalmat 2020 . február 20-án vizsgálták át $[21,22]$.

\section{Belgian Health Care Knowledge Centre (KCE)}

A belga irányelv a 2016-os angol NICE- és a 2017-es KCE-irányelven alapul, melyet az azóta megjelent releváns evidenciákkal bővítettek ki. Az irányelvet kifejlesztő csoportban 31 egészségügyi szakember vett részt különböző szakterületekről (háziorvos, rehabilitációs szakorvos, sebész, ortopéd és idegsebész szakorvos, fizioterapeuta, pszichológus, foglalkozásterapeuta, manuálterapeuta). Az eredeti szakirodalmi áttekintést 2011 és 2016 április 18-a között végezték [23, 24$].$

\section{Department of Veterans Affairs and the U.S. Department of Defense (VA/DoD)}

$\mathrm{Az}$ amerikai VA/DoD irányelv elkészítésében orvosok, gyógytornászok, ápolók, gyógyszerészek és egyéb egészségügyi szakemberek vettek részt. A szisztematikus irodalmi áttekintés 2006 januárjától 2016 szeptemberéig megjelent randomizált klinikai vizsgálatokat, rendszerezett áttekintő közleményeket és metaanalíziseket vizsgált. Az irányelv kifejlesztésének folyamatában egy páciensekből álló fókuszcsoport is részt vett. A kész szakmai irányelv összesen 38 ajánlást tesz, melyek közül 5 a diagnózis folyamatával, 33 pedig a kezeléssel foglalkozik [25].

\section{German Disease Management Guideline (GDMG)}

A német GDMG irányelvet 2015 és 2017 között dolgozták ki. A kidolgozásban 49 egészségügyi szakember vett részt minden releváns szakterületről, valamint 3 koordinátor. A nyilvánosság számára online lehetőséget biztosítottak a véleménynyilvánításra. Ezen javaslatokat Delphi-folyamatban értékelték a szakemberek [26]. Az adatgyưjtést a MEDLINE és Cochrane adatbázisokban végezték, és 172 publikációt választottak be az irányelv szintézisébe. Az irányelv 90 ajánlást tesz, melyek 2022ig vannak érvényben $[27,28]$.

\section{American College of Physicians (ACP)}

Az amerikai ACP-irányelv 2017-ben jelent meg. Kidolgozásában az ACP Klinikai Irányelvek Bizottságának tagjai vettek részt. A szisztematikus irodalmi áttekintések a 2008 januárjától 2015 áprilisáig megjelent publikációkra terjednek ki. 2016 novemberében ismételt iroda- lomkutatást végeztek. Az irányelv 3 összefoglaló ajánlást hoz, melyek a következő frissítésig vagy legkésőbb 2022 ig vannak érvényben [29].

\section{Scottish Intercollegiate Guidelines Network (SIGN)}

A skót SIGN-irányelv kidolgozása a SIGN-metódus által készült. Az eredeti szisztematikus irodalomkutatás a 2007 és 2012 között megjelent publikációkra terjedt ki. 2018-ban felülvizsgálták az irányelvet, és újabb irodalomkutatást végeztek, mely a 2014 és 2018 között megjelent, opioidokkal kapcsolatos publikációkra terjedt ki. Az ajánlások kidolgozásában 25 fó vett részt, köztük egészségügyi szakemberek (aneszteziológusok, háziorvosok, neurológusok, pszichiáterek, belgyógyászok, fizioterapeuták, pszichológusok, ápolók, foglalkozásterapeuták, gyógyszerészek, reumatológusok), páciensek és adatelemzők. Az irányelv frissített változatát 2019 augusztusában publikálták [30].

\section{Toward Optimized Practice (TOP)}

A kanadai TOP-irányelv alapját 11 nemzetközi irányelv adta, melyek 2003 és 2014 között jelentek meg. Az öszszehasonlításhoz a legfrissebb, harmadik kiadást használtuk, melyhez a szisztematikus irodalomkutatást a 2010 és 2014 között megjelent publikációk között végezték. Az irányelv kidolgozásában aneszteziológusok, radiológusok, háziorvosok, belgyógyászok, kineziológusok, ortopéd sebészek, gyógyszerészek, rehabilitációs szakorvosok, fizioterapeuták, pszichológusok és foglalkozásterapeuták vettek részt. Az irányelv felülvizsgálatát 2017ben hajtották végre, s ez jelenleg is érvényben van [31].

\section{Diagnosztika és rizikóbecslés}

A krónikus derékfájdalom jelentős százaléka a nem specifikus kategóriába tartozik, azaz a jelenleg rendelkezésre álló vizsgálati módszerekkel nem azonosítható a fájdalom állandósulásának hátterében körülírt fizikális eltérés. Az amerikai ACP-irányelv az egyetlen, amely az ajánlásaiban nem tér ki a diagnosztikára. A 6 másik nemzetközi irányelvben tett javaslatok, tekintettel a krónikus fájdalom természetére, a biopszichoszociális megközelítést hangsúlyozzák mind a diagnosztika, mind pedig a kezelési lehetőségek kiválasztásában. Az anamnézis kritikus eleme a súlyos organikus alapbetegségre utaló alarm tünetek („red flag”) azonosítása. Finucane és mtsai nemzetközi keretrendszert hoztak létre ezek átfogó vizsgálatára [32]. A legfontosabb fizikális eltéréseket és tüneteket az 1. táblázatban foglaltuk össze. Az alarm tünetek kizárása mellett a magatartási, a pszichológiai és a szociális faktorok figyelembevétele mindegyik irányelvben hangsúlyos. A belga, a német, a skót és az angol irányelv továbbá a felmérőskálák használatát is javasolja (például 
STarT Back, Örebro) [33]. A TOP-irányelv kivételével az ajánlások egyöntetúen ellenjavallják a képalkotó vizsgálatok rutinszerü használatát. Az irányelvek mindegyike kitér azonban arra, hogy elvégzésük csak akkor indokolt, ha súlyos organikus alapbetegség gyanúja merül fel, és/ vagy ha a kapott vizsgálati eredmény jelentősen befolyásolná a terápia kiválasztását. A német irányelv kitér arra, hogy krónikus fájdalom esetén a tünetek megváltozása indokolhatja a képalkotó vizsgálatok elvégzését.

Az irányelvekben először szerepel ajánlás a krónikussá válás rizikójának felmérésére. Az átfogó, pszichés és szociális faktorokra is kiterjedő anamnézis, valamint a fizikális vizsgálat után a krónikussá válás rizikója alacsony, közepes vagy magas besorolású lehet. Ennek célja, hogy már az első vizit alkalmával a megfelelő szintü és komplexitású terápiát lehessen felajánlani a páciensnek. Alacsony rizikó esetén például az egyszerúbb, kevésbé intenzív stratégiák elegendőek lehetnek (fizioterápia, kognitív viselkedésterápia), de magas rizikó esetén komplexebb, multidiszciplináris támogatást kell javasolni a páciensnek. A vizsgálatra és a rizikóbecslésre vonatkozó ajánlásokat a 2. táblázat foglalja össze.

\section{Tanácsadás és testmozgás mint elsődleges terápia}

Mindegyik irányelv a mozgás fokozását és az aktív életvitel fenntartását javasolja. A pihenés kerülése, a munkában maradásra és önmenedzselésre ösztönzés, valamint a széles körú információátadás az ACP-irányelv kivételével mindegyik ajánlásban hangsúlyos. A VA/DoD és SIGN irányelvek külön javaslatot tesznek a „fájdalomedukáció- ra" (pain neuroscience education, PNE), mely a páciensek számára kifejlesztett, a fájdalom neurofiziológiás folyamatainak megértését szolgáló, módszeres oktatást jelenti. A terápiára vonatkozó közös döntéshozatalt mint a páciensközpontú ellátás alappillérét a belga, a skót és a kanadai irányelv emeli ki.

Az aktív, nem gyógyszeres terápiák közül a rendszeres fizikai aktivitás kiemelten fontos krónikus fájdalom esetén, így első vonalbeli terápiaként szerepel mindegyik irányelvben. Eltéréseket csak a mozgás specifikusságára vonatkozóan látunk. Az egyéni gyógytorna-fizioterápiát a NICE kivételével mindegyik irányelv fontosnak tartja. A csoportos tornát a NICE-, az ACP- és a TOP-ajánlás is választandónak jelöli meg. A különböző mozgásformák között eltérő hangsúllyal szerepelnek az aerobikmozgások, az erősítő gyakorlatok, a pilates, a jóga, a tajcsi, a vízi torna és a törzsstabilizáció. Ez utóbbi olyan terápiás mozgásprogram, melynek célja a gerinc lokális, stabilizáló izmaiban az aktiválódási és motoros kontroll feltételezett diszfunkcióinak helyreállítása [34]. A SIGNirányelv az ajánlásaiban kitér arra, hogy a krónikus derékfájdalom kezelésében nincs elegendő evidencia arra, hogy bármilyen speciális mozgásforma hatékonyabb lenne a többinél. A kognitív viselkedésterápiát mindegyik irányelv erősen javasolja, főként a mozgásterápia kiegészítéseként. Emellett a NICE és a KCE kivételével az irányelvek javasolják még a relaxációt, a VA/DoD és az ACP pedig a „tudatos jelenlét” (mindfulness) gyakorlását is. Az aktív, nem gyógyszeres kezeléseket a 3. táblázat foglalja össze.

A passzív, nem gyógyszeres terápiák közül a manuálterápia alkalmazását a TOP kivételével mindegyik irányelv

1. táblázat | Organikus alapbetegségre utaló alarm tünetek („red flags”) derékfájdalom esetén (Finucane és mtsai [32], valamint Hartvigsen és mtsai [50] közleménye alapján)

\begin{tabular}{|c|c|c|}
\hline Potenciális kórkép & Rizikófaktorok & Gyakori fizikális eltérések és tünetek \\
\hline Csigolyatörés & $\begin{array}{l}\text { Osteoporosis; tartós kortikoszteroid- } \\
\text { használat; trauma; női nem; a gerincet } \\
\text { érintő korábbi fractura; nóknél >50 év, } \\
\text { férfiaknál >75 év }\end{array}$ & $\begin{array}{l}\text { Fájdalom a háti szakaszon; neurológiai tünetek (kétoldali; koordinációt és } \\
\text { járást érintő eltérések; vizelet-, széklettartási zavar); külsérelmi nyomok; ge- } \\
\text { rincérzékenység palpatióra, vibrációra; a gerinc görbületeinek hirtelen meg- } \\
\text { változása }\end{array}$ \\
\hline Malignus folyamatok & $\begin{array}{l}\text { Korábbi tumor (föleg emlő, prosztata, } \\
\text { tüdő, vese, pajzsmirigy) }\end{array}$ & $\begin{array}{l}\text { A tünetek progresszív romlása; éjszakai fájdalom; indokolatlan súlyvesztés } \\
\text { (a testsúly 5-10\%-a); neurológiai tünetek (kétoldali; koordinációt és járást } \\
\text { érintó eltérések; vizelet-, széklettartási zavar); gerincérzékenység palpatióra, } \\
\text { vibrációra; megváltozott érzékelés (nem dermatomalis) }\end{array}$ \\
\hline Cauda equina szindróma & $\begin{array}{l}\text { Discushernia; lumbalis stenosis; gerinc- } \\
\text { mútét }\end{array}$ & $\begin{array}{l}\text { Egyoldali vagy kétoldali radicularis fájdalom; dermatomának megfelelő } \\
\text { csökkent érzékelés; myotomiának megfelelö gyengeség; csökkent érzékelés } \\
\text { a nyereg területén; vizelet-, széklettartási zavar; szexuális diszfunkciók; de- } \\
\text { rékfájdalomhoz kapcsolódó váltakozó lábfájdalom; derékfájdalomhoz kap- } \\
\text { csolódó motorosfunkció-gyengülés, -kiesés; a lábat érintő tünetek (fájda- } \\
\text { lom, görcsök, zsibbadás) járás közbeni fokozódása }\end{array}$ \\
\hline $\begin{array}{l}\text { Infekció (spondylodisci- } \\
\text { tis, osteomyelitis, } \\
\text { epiduralis tályog) }\end{array}$ & $\begin{array}{l}\text { Immunszuppresszió (társbetegségek } \\
\text { fontossága); ismételt gerincmútét; int- } \\
\text { ravénás droghasználat; tuberkulózis; } \\
\text { megelőzô fertőzés, septicaemia }\end{array}$ & $\begin{array}{l}\text { Lokalizált, progresszív gerincfájdalom; neurológiai tünetek (kétoldali; } \\
\text { koordinációt és járást érintő eltérések; vizelet-, széklettartási zavar); kime- } \\
\text { rültség (fatigue); láz; indokolatlan súlyvesztés; gerincérzékenység palpatió- } \\
\text { ra, vibrációra; radiculopathia }\end{array}$ \\
\hline Axialis spondyloarthritis & $\begin{array}{l}\text { Életkor: } 20-40 \text { év; családi halmozódás; } \\
H L A-B 27 \text { gén }\end{array}$ & $\begin{array}{l}\text { Reggeli gerincmerevség, amely mozgásra javul, pihenésre azonban nem; } \\
\text { váltakozó fartáji fájdalom; NSAID-re jelentôsen javulnak a panaszok }\end{array}$ \\
\hline
\end{tabular}

NSAID = nemszteroid gyulladáscsökkentő gyógyszer 
2. táblázat |Az anamnézisre vonatkozó ajánlások összehasonlítása krónikus fájdalom esetén

\begin{tabular}{|c|c|c|c|c|c|c|c|}
\hline Irányelv & VA/DoD & KCE & NICE & GDMG & ACP & SIGN & TOP \\
\hline Ország & USA & Belgium & $\begin{array}{l}\text { Egyesült } \\
\text { Királyság }\end{array}$ & Németország & USA & Skócia & Kanada \\
\hline $\begin{array}{l}\text { Publikáció, } \\
\text { frissítés }\end{array}$ & P: 2019 & $\begin{array}{l}\text { P: } 2017 \\
\text { F: } 2020\end{array}$ & $\begin{array}{l}\text { P: } 2016 \\
\text { F: } 2020\end{array}$ & $\begin{array}{l}\text { P: } 2017 \\
\text { É: } 2022\end{array}$ & $\begin{array}{l}\text { P: } 2017 \\
\text { É: } 2022\end{array}$ & $\begin{array}{l}\text { P: } 2013 \\
\text { F: } 2019\end{array}$ & $\begin{array}{l}\text { P: } 2015 \\
\text { F: } 2017\end{array}$ \\
\hline \multicolumn{8}{|l|}{ Vizsgálat } \\
\hline Alarm tünetek kizárása („red flags”) & $\uparrow \uparrow$ & $\uparrow \uparrow$ & $\uparrow \uparrow$ & $\uparrow \uparrow$ & & $\uparrow$ & $\uparrow \uparrow$ \\
\hline Felmérőskála & & $\uparrow^{*}$ & $\uparrow^{*}$ & $\uparrow^{*}$ & & $\uparrow^{*}$ & $\leftrightarrow^{*}$ \\
\hline $\begin{array}{l}\text { Rizikófelmérés, rizikócsoportba való } \\
\text { besorolás }\end{array}$ & & $\uparrow \uparrow$ & $\uparrow \uparrow$ & & & & \\
\hline Pszichoszociális faktorok felmérése & $\uparrow$ & $\uparrow$ & & $\uparrow \uparrow$ & & $\uparrow$ & $\uparrow$ \\
\hline \multicolumn{8}{|l|}{ Képalkotó vizsgálatok és labor } \\
\hline $\begin{array}{l}\text { Képalkotó, } \\
\text { laborvizsgálatok }\end{array}$ & $\downarrow \downarrow+$ & $\downarrow \downarrow+$ & $\downarrow \downarrow+$ & $\downarrow \downarrow+$ & & & $\uparrow+$ \\
\hline
\end{tabular}

Jelmagyarázat: $\uparrow \uparrow=$ erős ajánlás; $\uparrow$ = gyenge ajánlás; $\varnothing=$ nincs ajánlás, elégtelen evidencia miatt; $\leftrightarrow$ = egyéni megfontolás, nincs ajánlás; $\downarrow=$ gyenge ellenjavallat; $\downarrow \downarrow=$ erôs ellenjavallat

$\mathrm{P}=$ publikálva; $\mathrm{F}=$ frissítve; $\mathrm{E}$ = érvényes

* = STarT Back, Örebro

+ Kivéve $=$ „red flag”-ek megléte, vagy ha az eredmény befolyásolná a terápiát

$\mathrm{ACP}=$ Amerikai Orvosi Kollégium; GDMG = Német Betegségkezelési Irányelv; KCE = Belga Egészségügyi Tudásközpont; NICE $=$ Az Egészség és Klinikai Kiválóság Nemzeti Intézete (Egyesült Királyság); SIGN = Skót Egyetemi Irányelvek Hálózata; TOP = Toward Optimized Practice; VA/DoD = az USA Veteránügyi Minisztériuma és Védelmi Minisztériuma

3. táblázat |A tanácsadás és az aktív, nem gyógyszeres kezelések összehasonlítása

\begin{tabular}{|c|c|c|c|c|c|c|c|}
\hline \multirow[t]{2}{*}{ Irányelv } & VA/DoD & KCE & NICE & GDMG & ACP & SIGN & TOP \\
\hline & $C L B P$ & $C L B P$ & $C L B P$ & $C L B P$ & $C L B P$ & $C L B P$ & $C L B P$ \\
\hline \multicolumn{8}{|l|}{ Tanácsadás } \\
\hline Aktív életvitel, mozgás & $\uparrow \uparrow$ & $\uparrow \uparrow$ & $\uparrow \uparrow$ & $\uparrow \uparrow$ & $\uparrow$ & $\uparrow$ & $\uparrow$ \\
\hline Pihenés & $\downarrow \downarrow$ & $\downarrow \downarrow$ & $\downarrow \downarrow$ & $\downarrow \downarrow$ & & $\downarrow$ & $\downarrow$ \\
\hline A munkában maradásra ösztönzés & $\uparrow \uparrow$ & $\uparrow \uparrow$ & $\uparrow \uparrow$ & $\uparrow \uparrow$ & & $\uparrow$ & $\uparrow$ \\
\hline Közös döntéshozatal & & $\uparrow \uparrow$ & & & & $\uparrow$ & $\uparrow$ \\
\hline Információ és edukáció a derékfájdalomról & $\uparrow \uparrow$ & $\uparrow \uparrow$ & $\uparrow \uparrow$ & $\uparrow \uparrow$ & & $\uparrow$ & $\uparrow$ \\
\hline Fájdalomedukáció & $\begin{array}{l}\uparrow \\
\text { PNE }\end{array}$ & & & & & $\begin{array}{l}\uparrow \\
\text { PNE }\end{array}$ & \\
\hline Önmenedzselés & $\uparrow \uparrow$ & & $\uparrow \uparrow$ & & & $\uparrow$ & $\uparrow$ \\
\hline \multicolumn{8}{|l|}{ Aktíp, nem gyógyszeres terápiák } \\
\hline Fizioterápia, mozgásterápia, gyógytorna & $\uparrow$ & $\uparrow$ & & $\uparrow$ & $\uparrow$ & $\uparrow$ & $\uparrow$ \\
\hline Kognitív viselkedésterápia & $\uparrow \uparrow$ & $\begin{array}{l}\text { १ } \\
\text { Kieg. }\end{array}$ & $\begin{array}{l}\text { ^ } \\
\text { Kieg. }\end{array}$ & $\uparrow \uparrow$ & $\uparrow$ & $\uparrow$ & $\uparrow$ \\
\hline Relaxáció & $\uparrow$ & & & $\uparrow$ & $\uparrow$ & $\uparrow$ & $\uparrow$ \\
\hline Mindfulness & $\uparrow$ & & & & $\uparrow$ & & $\varnothing$ \\
\hline Csoporttorna & & & $\uparrow$ & & $\uparrow$ & & $\uparrow$ \\
\hline Multidiszciplináris rehabilitációs program & $\uparrow \uparrow$ & $\uparrow \uparrow$ & $\uparrow \uparrow$ & $\uparrow \uparrow$ & $\uparrow$ & $\uparrow$ & $\uparrow$ \\
\hline
\end{tabular}

Jelmagyarázat: $\uparrow \uparrow=$ erôs ajánlás; $\uparrow=$ gyenge ajánlás; $\varnothing=$ nincs ajánlás, elégtelen evidencia miatt; $\leftrightarrow$ = egyéni megfontolás, nincs ajánlás; $\downarrow=$ gyenge ellenjavallat; $\downarrow \downarrow=$ erôs ellenjavallat

$\mathrm{ACP}=$ Amerikai Orvosi Kollégium; CLBP $=$ krónikus derékfájdalom; GDMG = Német Betegségkezelési Irányelv; KCE $=$ Belga Egészségügyi Tudásközpont; Kieg. = kiegészítő terápia; NICE = Az Egészség és Klinikai Kiválóság Nemzeti Intézete (Egyesült Királyság); PNE = fájdalomedukáció; SIGN = Skót Egyetemi Irányelvek Hálózata; TOP = Toward Optimized Practice; VA/DoD = az USA Veteránügyi Minisztériuma és Védelmi Minisztériuma 
javasolja vagy megfontolandónak tartja, de csak a mozgásterápia kiegészítéseként. Önálló terápiaként azonban csak a SIGN és az ACP javasolja, rövid ideig. A kanadai irányelv erre vonatkozóan az elégtelen evidencia miatt nem tesz ajánlást. A gerinctrakció a VA/DoD-, az ACPés a TOP-irányelv kivételével ellenjavallt. A derékövek és a talpbetétek ellenjavalltak. Az ultrahang használatát a TOP egyéni elbíráláshoz köti, míg a többi irányelv ellenjavallja, mivel hatékonysága nem bizonyított. Az elektroterápiák közül a transzkután elektromos idegstimulációt (TENS) egyedül a skót irányelv ajánlja, míg a TOP csak kiegészítő kezelésként javasolja. A többi irányelv nem javasolja a használatát. Az elektromos izomstimulációval egybekötött „biofeedback” használatát az ACP és a SIGN javasolja. Az akupunktúra terápiás használatát a skót, a kanadai és mindkét amerikai irányelv enyhén ajánlja, a német megfontolandónak tartja, míg az angol nem javasolja. Egységesek viszont az ajánlások arra vonatkozóan, hogy akiknél a krónikussá válás rizikója magas, és/vagy az előző terápiák nem vezettek sikerre, multidiszciplináris rehabilitációs programban való részvétel javasolt.

\section{A gyógyszeres terápiák háttérbe szorulása}

A krónikus fájdalom kezelésére vonatkozó gyógyszeres terápiák ajánlásában az irányelvek erősen megoszlanak. Egyedül a nemszteroid gyulladáscsökkentőket (NSAID) javasolják egyöntetúen, kitérve arra, hogy a lehetséges mellékhatásokról tájékoztatni kell a pácienst, valamint felírásuknál a legkisebb terápiás dózist kell választani, a lehető legrövidebb ideig. A paracetamolt a belga, a német és az angol irányelv egyedüli gyógyszeres terápiaként nem ajánlja, a kanadai viszont igen. A VA/DoD ajánlás hosszú távon egyáltalán nem javasolja a használatát (rövid távú alkalmazására nem tesz ajánlást). A kortikoszteroidok alkalmazását a VA/DoD és a NICE nem javasolja, a többi irányelv nem tér ki a használatukra. Az opioidok alkalmazására vonatkozó ajánlások megoszlanak. A VA/DoD, a KCE és a NICE egyáltalán nem javasolja, míg a német, a skót és a kanadai irányelv egyéni elbíráláshoz köti az alkalmazásukat, akkor is csak rövid távon. Az ACP-ajánlás utolsó terápiás lehetőségként jelöli, ha semmilyen megelőző kezelés nem használt. A szerotonin-noradrenalin visszavétel gátlók (SNRI-k) használatában az ajánlások eltérőek: a NICE-irányelv ellenjavallja, míg a KCE, a VA/DoD és az ACP enyhe ajánlást tesz az alkalmazásukra. A szelektív szerotoninvisszavétel-gátlók (SSRI-k) azonban nem ajánlottak. $\mathrm{Az}$ antikonvulzív szerek a belga és a skót irányelv szerint neuropátiás komponens esetén megfontolandók, míg a német és az angol nem javasolja a használatukat.

A NICE-irányelv külön kitér az akut és a krónikus ülőideg radicularis fájdalom (isiász) gyógyszeres kezelésére is. A gabapentin, az oralis kortikoszteroidok és a benzodiazepinek radicularis fájdalom esetén nem javasoltak. A NSAID használatát illetően nem ad ajánlást a rendel- kezésre álló, elégtelen evidencia miatt. A mellékhatásokról és a rizikófaktorokról való tájékoztatást viszont erősen ajánlja. Krónikus ülőideg-érintettség esetén továbbá az opioidok adását sem javasolja a NICE-irányelv. A farmakoterápiára vonatkozó javaslatok összehasonlítása a 4. táblázatban látható.

Az invazív terápiákat illetően csak a legfontosabb ajánlásokat emeljük ki. Az irányelvek döntő többsége a gerincinjekciókat a fájdalom hosszú távú kezelésére nem javasolja. A GDMG irányelv szinte semelyik injekciós és / vagy mútéti terápiát nem ajánlja krónikus, nem specifikus derékfájdalom esetén. A KCE és a NICE irányelvek a dekompressziós mútétet és a rádiofrekvenciás denervációt csak a multidiszciplináris terápia sikertelensége esetén, egyéni mérlegelés után ajánlják. A gerincfúziós mútéteket a NICE-irányelv ellenjavallja, kivéve, ha randomizált kontrollált kísérlet részeként végzik őket.

\section{A nemzetközi irányelvek alkalmazása a mindennapi gyakorlatban}

Az irányelvek a derékfájdalom vizsgálatát és diagnosztikáját, valamint az elsőként választandó terápiás lehetőségeket tekintve egyfajta konszenzusra jutottak. A képalkotó vizsgálatok rutinszerü használata ellenjavallt. A radiológiai vizsgálatok többletinformációt szolgáltatnak az esetleges háttérfolyamatokról, mint ahogy azt Horváth és mtsai 2010-es, magyar mintán végzett vizsgálatukban is igazolták. Az általuk vizsgált, derékfájdalommal élő pácienseknél 57,5\%-ban tudtak degeneratív ágyéki eltérést azonosítani [35]. Azonban az alarm tünetek és/vagy neurológiai deficitek hiányában végzett képalkotó vizsgálatok ritkán befolyásolják a már kiválasztott terápiát. Chou és mtsai 2009. évi, szisztematikus áttekintő vizsgálata szerint akut és szubakut derékfájdalom esetén 3, 6 és 12 hónap után nem volt különbség azon páciensek fájdalomintenzitása és kezelése között, akiknél képalkotó vizsgálatokat végeztek, azokhoz képest, akiknél nem [36]. Továbbá a rutinszerú képalkotó vizsgálatok szükségtelen terápiákhoz, megnövekedett költségekhez és a fájdalom fennmaradásához is vezethetnek [37]. Chou és mtsai 2011-es szisztematikus áttekintése nem talált bizonyítékot arra, hogy krónikus derékfájdalom esetén a képalkotó vizsgálatok rutinszerü elvégzése indokolt lenne [38].

A krónikussá válás rizikójának korai felmérése a megfelelő terápiás döntéshozatal kiemelt eleme. Ezen kockázati tényezők feltérképezésére a belga irányelv a zászlós rendszer használatát javasolja. A zászlós rendszer színkódokkal jelöli a különböző rizikócsoportokat (piros, narancssárga, sárga, kék, fekete) [39]. A piros zászlók a különböző súlyos kórállapotokat jelölik. A narancssárga zászlók olyan pszichiátriai kórképek meglétére utalnak, mint a depresszió vagy a személyiségzavar. A sárga zászlók olyan pszichológiai tüneteket jelölnek, melyek hozzájárulnak a fájdalom krónikussá válásához, úgymint a diszfunkcionális attitűdök és elvárások, a félelem, a szo- 
4. táblázat |A farmakoterápiás ajánlások összehasonlítása

\begin{tabular}{|c|c|c|c|c|c|c|c|c|}
\hline Irányelv & VA/DoD & KCE & NICE & & NMDG & ACP & SIGN & TOP \\
\hline & $C L B P$ & $C L B P$ & Isiász & $C L B P$ & $C L B P$ & $C L B P$ & $C L B P$ & $C L B P$ \\
\hline \multicolumn{9}{|l|}{ Gyógyszeres terápiák } \\
\hline Paracetamol & $\downarrow \downarrow$ HØR & $\downarrow^{*}$ & $\downarrow^{*}$ & $\downarrow^{*}$ & $\downarrow$ & & $\varnothing$ & $\uparrow$ \\
\hline Oralis NSAID & $\uparrow \uparrow !$ & $\uparrow \# !$ & $\varnothing \# !$ & $\uparrow \# !$ & $\uparrow$ & $\uparrow$ & $\uparrow !$ & $\uparrow$ \\
\hline Lokális NSAID & & & & & & & $\uparrow$ & \\
\hline SNRI (duloxetin) & $\uparrow$ & $\uparrow$ & & $\downarrow$ & & $\uparrow$ & $\varnothing \mathrm{K}$ & $\varnothing$ \\
\hline SSRI & $\varnothing$ & & & $\downarrow$ & & $\downarrow$ & $\varnothing \mathrm{K}$ & $\downarrow$ \\
\hline Antikonvulzív gyógyszerek (gabapentin, pregabalin) & & $\leftrightarrow \mathrm{N}$ & $\downarrow$ & $\downarrow$ & $\downarrow$ & & $\uparrow N$ & \\
\hline Triciklikus antidepresszánsok & & & & $\downarrow$ & & $\downarrow$ & $\downarrow$ & $\uparrow$ \\
\hline Benzodiazepinek & $\downarrow$ & $\downarrow$ & $\downarrow$ & & & & & $\uparrow \mathrm{E}$ \\
\hline Centrális izomrelaxánsok & $\downarrow$ & $\downarrow \downarrow$ & & & $\downarrow \downarrow$ & & & \\
\hline Szisztémás kortikoszteroidok & $\downarrow \downarrow$ & & $\downarrow$ & & & & & \\
\hline Opioidok & $\begin{array}{l}\downarrow \mathrm{H} \\
\varnothing \mathrm{R}\end{array}$ & $\downarrow \downarrow$ & $\downarrow$ & $\downarrow$ & $\leftrightarrow \mathrm{E}$ & $\uparrow \mathrm{U}$ & $\uparrow \mathrm{E} \#$ & $\begin{array}{l}\varnothing \mathrm{H} \\
\leftrightarrow \mathrm{R}\end{array}$ \\
\hline Antibiotikum & & $\downarrow$ & & & & & & $\downarrow$ \\
\hline
\end{tabular}

Jelmagyarázat: $\uparrow \uparrow=$ erős ajánlás; $\uparrow=$ gyenge ajánlás; $\varnothing=$ nincs ajánlás, elégtelen evidencia miatt; $\leftrightarrow=$ egyéni megfontolás, nincs ajánlás; $\downarrow=$ gyenge ellenjavallat; $\downarrow \downarrow=$ erős ellenjavallat

$!$ = rizikómonitorozás

\# = legrövidebb ideig, legkisebb terápiás dózis

* = egyedüli terápiaként nem javasolt

$\mathrm{E}$ = egyéni elbírálás; $\mathrm{H}$ = hosszú távú; $\mathrm{K}$ = rendszeres kontroll; $\mathrm{N}$ = neuropátiás komponens esetén; $\mathrm{R}$ = rövid távú; $\mathrm{U}$ = utolsó terápiás lehetőség

$\mathrm{ACP}=$ Amerikai Orvosi Kollégium; CLBP = krónikus derékfájdalom; GDMG = Német Betegségkezelési Irányelv; KCE = Belga Egészségügyi Tudásközpont; NICE = Az Egészség és Klinikai Kiválóság Nemzeti Intézete (Egyesült Királyság); NSAID = nemszteroid gyulladáscsökkentő gyógyszer; PNE = fájdalomedukáció; SIGN = Skót Egyetemi Irányelvek Hálózata; SNRI = szerotonin-noradrenalin visszavétel gátló; SSRI = szelektív szerotoninvisszavétel-gátló; TOP = Toward Optimized Practice; VA/DoD = az USA Veteránügyi Minisztériuma és Védelmi Minisztériuma

rongás vagy az elkerülő magatartás. A kék zászlók a munka és az egészség közti kapcsolat feltérképezésére szolgálnak, míg a fekete zászlók azokat a faktorokat jelölik, melyekre a páciensnek nincs közvetlen hatása, ilyen a munkahelyi környezet és a társadalmi helyzet. A rizikófaktorok megléte alapján alacsony, közepes vagy magas lehet a krónikussá válás esélye, ami különböző szintű kezelést von maga után. Így azoknál a pácienseknél, ahol a rizikó alacsony, a standard terápia is elegendő lehet, míg magas rizikó esetén komplex, multidiszciplináris terápia megkezdése javasolt [23].

A zászlós rendszer mellett a standardizált, validált felmérőskálák hétköznapi gyakorlatba való beépítése is segíti a rizikóbecslést. A belga, a német és az angol irányelv mindegyike a STarT Back vagy az Örebro-kérdőív használatát javasolja [40]. A STarT Back kérdőív adaptációja (STarT-H) Szita és mtsai munkájának köszönhetően már magyar nyelvre is validált és elérhető [41]. Kutatási eredményeikből az is kiderül, hogy a STarT-H felmérőskála a terápia eredményességének előrevetítésére is alkalmas lehet. A rizikócsoportok segítségével a páciensek az állapotuknak megfelelő, komplex kezelésben részesülhetnek, elkerülve a terápiák túl- vagy aluldozírozását. Ez nemcsak a pácienseknek, de az egészségügyi ellátórendszernek is érdeke.

Lin és mtsai 2020. évi rendszerezett, áttekintő közleményükben azonosították és összefoglalták a 2016-ig megjelent, mozgásszervi fájdalmak kezelését célzó nemzetközi irányelvek megegyező pontjait [42]. A 11 pont részleteit az 5. táblázat foglalja össze. Az ajánlások a jelen összefoglalóhoz hasonlóan az aktív stratégiák alkalmazását hangsúlyozzák a krónikus fájdalom kezelésére és a krónikus fájdalomba való átmenet megakadályozására. Az irányelvekben feldolgozott tudományos kutatások az aktív fizioterápiák fájdalomcsökkenésre gyakorolt hatása tekintetében többnyire alacsony vagy közepes evidenciaszinttel rendelkeznek. Ennek ellenére mégis első vonalbeli terápiaként szerepelnek, feltehetően azért, mert adverz hatást ritkán váltanak ki, viszont pozitívan befolyásolják a szövetek állapotát, valamint a pszichés és szociális tényezőket egyaránt (a depresszió és a szorongásos zavarok csökkenése) [43]. Ilyen aktív stratégia lehet a felügyelt, személyre szabott mozgásterápia, az otthon végezhető torna, szükség esetén manuálterápiás technikákkal és pszichoterápiával megtámogatva. A mozgásterápia során a fizioterapeutáknak a páciens céljaira kell fókuszálniuk, mintsem egy specifikus mozgásmódszer 
A krónikus mozgásszervi fájdalmakra vonatkozó nemzetköz irányelvekben egységesen megjelenő ajánlások ( Lin és mtsai köz leménye alapján [42])

1. Alapvető a páciensközpontú ellátás, melynek kiemelt részei:

a) a páciens egyéni helyzetének figyelembevétele

b) a megfelelő kommunikáció

c) a közös döntéshozatal

2. A súlyos kórállapotok, organikus alapbetegségek, alarm tünetek („red flag”) szűrése, kizárása

3. A pszichoszociális faktorok vizsgálata

4. A radiológiai vizsgálatok ellenjavalltak, kivéve:

a) ha súlyos kórállapot erós gyanúja áll fenn

b) ha a konzervatív terápia nem hoz kívánt eredményt, vagy a tünetekben megmagyarázhatatlan progresszió következik be

c) ha a képalkotó eredménye nagyban befolyásolná a terápiaválasztást

5. A fizikális vizsgálat elvégzése, amely a neurológiai vizsgálatot, az ízületi mobilitás és/vagy izomerô vizsgálatát is magában foglalja

6. A páciens állapotváltozásának felmérése és nyomon követése (felmérőskálák)

7. A páciensek oktatása és megfelelő információ nyújtása a helyzetükről és terápiás lehetőségeikről

8. A fizikai aktivitást és/vagy tornát magában foglaló kezelés

9. A manuálterápia alkalmazása csak kiegészítő terápiaként

10. A mútétek ellenjavallata a különleges esetek kivételével

11. A munka folytatása vagy a munkába való visszatérés segítése

lépéseire, mivel ezek között hatékonyságbeli különbség a nemzetközi evidenciák tükrében nem mutatható ki. Owen és mtsai metaanalízisükben azt találták, hogy a fájdalom csökkentésére a pilates, a „stabilizáló gyakorlatok", az aerobikmozgások és az ellenállással szemben végzett mozgások egyaránt hatékonyak [44]. Az aktív terápiának továbbá részét képezi a megfelelő információ átadása, az edukáció, az aktivitás fokozatos visszavezetése („graded activity”), a relaxáció és a légzőtechnikák megtanítása, valamint a munkába és a sportba való viszszatérés vagy a sportolás folytatásának facilitálása. Steffens és mtsai 2016. évi szisztematikus áttekintése alapján pedig az is elmondható, hogy közepes erősségű bizonyítékok támasztják alá, hogy a mozgás önmagában vagy edukációval kiegészítve hatékony a derékfájdalom megelőzésében [45].

Szembetűnő lehet, hogy a gyógyszeres vagy invazív terápiák alkalmazásában csekély egyezés látható az irányelvek között. Illés a 2015-ös összefoglalójában már kitért arra, hogy a krónikus derékfájdalmak gyógyszeres terápiájában sok a bizonytalanság [46]. Ennek egyik oka az lehet, hogy a jelenlegi evidencia a gyógyszeres terápiák hatását illetően a krónikus derékfájdalom és a radicularis fájdalom kezelésére - a folyamatos kutatások ellenére is inkább gyengének mondható. Jól mutatja ezt a NICEirányelv 2020-ban elvégzett felülvizsgálata is, amely csak a farmakoterápiában eszközölt változtatásokat. Az ülő- ideg radicularis fájdalma esetén erősen ellenjavallttá váltak a gabapentinek, antiepileptikumok, benzodiazepinek, mert ugyan limitált evidencia rendelkezésre áll arról, hogy nem hatékonyak, de a mellékhatások túlsúlya egyértelmű a terápiás előnyökkel szemben. A NICE-irányelv továbbá kitér arra is, hogy ha a páciens már ezen terápiák valamelyike alatt áll, informálni kell a mellékhatásokról és a hosszú távú szedés következményeiről. A krónikus derékfájdalom gyógyszeres kezelésében az NSAID-ok ajánlása tekintetében nem volt változás az elmúlt években, bár a szakirodalomban fellelhető olyan metaanalízis, mely szerint hatékonyságuk klinikailag nem jelentősebb a placebóénál [47].

$\mathrm{Az}$ irányelvek, fóként a belga és a német, kiemelik a fájdalomspecialista, rehabilitációs szakorvosok szerepét a krónikus derékfájdalmak menedzselését illetően. Szekanecz emellett már egy 2010-es publikációjában hangsúlyozta, hogy a háziorvosoknak és a szakorvosoknak kiemelt szerepük van a diagnózisban és a rehabilitációban. Továbbá a konzervatív kezelés sikeréért mindent meg kell tenniük, tekintve, hogy az evidenciák tükrében sem a gyógyszeres, sem pedig az invazív terápiáktól nem várható tartós javulás [48]. Abban az esetben, ha az összes lépést végigjárta a páciens, de fájdalma változatlanul fennáll, a fájdalommentesség elérése helyett a funkcionálisan élhetó életre kell áthelyezni a fókuszt, és a lehető legjobb állapotban kell tartani a pácienst. Ehhez a támogató és az elfogadást segítő terápiák nyújtanak segítséget, úgymint a kognitív viselkedésterápia (CBT) vagy az Elfogadás és Elköteleződés Terápia (ACT) [49].

\section{Következtetések}

A krónikus derékfájdalom egyre növekvő terhet jelent mind az egyén, mind az egészségügyi szolgáltatók, mind pedig a társadalom számára. Bár a derékfájást célzó terápiák száma egyre növekszik, nincs tudomásunk olyan magyar szakmai irányelvről, mely célzottan összefoglalná és megvizsgálná ezen kezelések hatékonyságát. Összefoglalónk céljaként azt határoztuk meg, hogy a nemzetközi irányelvek jelenleg is hatályos, magas minőségú besorolással rendelkező ajánlásaiból kiemelje a krónikus deréktáji fájdalomra vonatkozó javaslatokat, ezzel is támogatva az ellátásban részt vevő szakemberek és a páciensek döntéshozatali folyamatát.

A derékfájdalom évtizedek óta vezető helyen áll az életvitelt korlátozó betegségek listáján. Ahhoz, hogy hatékonyan tudjunk enyhíteni a páciensek és az egészségügy terhein, következetes, stratégiai változtatásokra van szükség. A 2018-as évben a Lancet szakfolyóirat derékfájással foglalkozó tematikus számában a Derékfájdalommal Foglalkozó Munkacsoport a nemzetközi irányelvekkel azonos ajánlások mellett az egészségügyi rendszer algoritmusának megváltoztatását, a foglalkozás-egészségügy fejlesztését, a derékfájdalmat körülölelő tévhiteknek (például hogy a fájdalom minden esetben szöveti sérülést és károsodást jelent), valamint az olyan hátrá- 
nyos magatartásmintáknak, mint a fájdalom kapcsán jelentkező inaktivitás, a társadalmi szintü leépítését is kiemeli. A közlemény szerint a fentiek együttese szükséges ahhoz, hogy globális mértékben csökkenjen a derékfájdalom prevalenciája $[10,50]$. Tanulmányunk mindezek alapján segítheti a terápiás döntéshozatalt és a segítő szakmákon belüli kollaborációt a krónikus deréktáji fájdalom sikeresebb kezelése reményében, így közös erőfeszítésekkel pozitív változások érhetők el magyar viszonylatokban is.

A bővített táblázatokat készséggel megküldjük az érdeklődőknek.

Anyagi támogatás: A szerzők a közlemény megírása során anyagi támogatásban nem részesültek.

Szerzôi munkamegosztás: F.-K. K.: Az alapkoncepció kidolgozása, a kézirat megírása, az irodalom összeállítása, adatgyüjtés. M. J.: Az alapkoncepció kidolgozása, a kézirat szerkesztése, szövegezése. Á. Sz.: Az alapkoncepció kidolgozása, a kézirat szövegezése és szerkesztése. A cikk végleges változatát valamennyi szerző elolvasta és jóváhagyta.

Érdekeltségek: A szerzőknek nincsenek érdekeltségeik.

\section{Irodalom}

[1] Breivik H, Collett B, Ventafridda V, et al. Survey of chronic pain in Europe: prevalence, impact on daily life, and treatment. Eur J Pain 2006; 10: 287-333.

[2] Goldberg DS, McGee SJ. Pain as a global public health priority. BMC Public Health 2011; 11: 770.

[3] Cieza A, Causey K, Kamenov K, et al. Global estimates of the need for rehabilitation based on the Global Burden of Disease study 2019: a systematic analysis for the Global Burden of Disease Study 2019. Lancet 2020; 396: 2006-2017.

[4] Hungarian Central Statistical Office. We can do for our health. European health interview survey 2019. [Tehetünk az egészségünkért. 2019. évi Európai lakossági egészségfelmérés.] Központi Statisztikai Hivatal, Budapest, 2020. Available from: https://www.ksh.hu/docs/hun/xftp/idoszaki/elef/te_2019/ index.html [accessed: January 18, 2021]. [Hungarian]

[5] Horváth G, Than P, Bellyei Á, et al. Prevalence of musculoskeletal symptoms in adulthood and adolescence (survey conducted in the Southern Transdanubian region in a representative sample of 10.000 people). [Mozgásszervi panaszok gyakorisága felnőttés serdülőkorban (Reprezentatív felmérés a Dél-Dunántúlon 10 ezer fős mintán).] Orv Hetil. 2006; 147: 351-356. [Hungarian]

[6] Dionne CE, Dunn KM, Croft PR, et al. A consensus approach toward the standardization of back pain definitions for use in prevalence studies. Spine (Phila PA 1976) 2008; 33: 95-103.

[7] Nicholas M, Vlaeyen JW, Rief W, et al. The IASP classification of chronic pain for ICD-11: chronic primary pain. Pain 2019; 160: $28-37$.

[8] Vos T, Allen C, Arora M, et al., GBD 2015 Disease and Injury Incidence and Prevalence Collaborators. Global, regional, and national incidence, prevalence, and years lived with disability for 310 diseases and injuries, 1990-2015: a systematic analysis for the Global Burden of Disease Study 2015. Lancet 2016; 388: 1545-1602. [Erratum: Lancet 2017; 389(10064): el.]
[9] International Association for the Study of Pain. 2021 Global year about back pain. Available from: https://www.iasp-pain.org/ GlobalYear [accessed: January 18, 2021].

[10] Foster NE, Anema JR, Cherkin D, et al. Prevention and treatment of low back pain: evidence, challenges, and promising directions. Lancet 2018; 391: 2368-2383.

[11] Ministry of Human Resources. 18/2013. (III.5.) EMMI regulation on uniform rules for the development, drafting and conducting of professional consultations concerning diagnostic and therapeutic procedures. [18/2013. (III. 5.) EMMI rendelet a vizsgálati és terápiás eljárási rendek kidolgozásának, szerkesztésének, valamint az ezeket érintő szakmai egyeztetések lefolytatásának egységes szabályairól.] Eü Közl. 2013; 63: 978-983. Available from: https://net.jogtar.hu/jogszabaly?docid= al300018.emm [accessed: January 18, 2021]. [Hungarian]

[12] Shekelle PG, Ortiz E, Rhodes S, et al. Validity of the Agency for Healthcare Research and Quality clinical practice guidelines: how quickly do guidelines become outdated? JAMA 2001; 286: 1461-1467.

[13] Ministry of Human Resources. National healthcare guideline: Pharmacist advice for self-treatment of acute non-specific low back pain. [Egészségügyi szakmai irányelv: Az akut nem specifikus derékfájás öngyógyításának gyógyszerészi tanácsadásáról.] Emberi Erőforrások Minisztériuma, Budapest, 2018. Available from: https://kollegium.aeek.hu/Download/Download/3367 [accessed: January 16, 2021]. [Hungarian]

[14] Brouwers MC, Kho ME, Browman GP, et al. AGREE II: Advancing guideline development, reporting, and evaluation in health care. CMAJ 2010; 182: E839-E842.

[15] Meroni R, Piscitelli D, Ravasio C, et al. Evidence for managing chronic low back pain in primary care: a review of recommendations from high-quality clinical practice guidelines. Disabil Rehabil. 2021; 43: 1029-1043.

[16] Krenn C, Horvath K, Jeitler K, et al. Management of non-specific low back pain in primary care - A systematic overview of recommendations from international evidence-based guidelines. Prim Health Care Res Dev. 2020; 21: e64.

[17] Castellini G, Iannicelli V, Briguglio M, et al. Are clinical practice guidelines for low back pain interventions of high quality and updated? A systematic review using the AGREE II instrument. BMC Health Serv Res. 2020; 20: 970.

[18] Ng JY, Mohiuddin U, Azizudin AM. Clinical practice guidelines for the treatment and management of low back pain: a systematic review of quantity and quality. Musculoskelet Sci Pract. 2021; 51: 102295 .

[19] Doniselli FM, Zanardo M, Manfrè L, et al. A critical appraisal of the quality of low back pain practice guidelines using the AGREE II tool and comparison with previous evaluations: a EuroAIM initiative. Eur Spine J. 2018; 27: 2781-2790.

[20] Shekelle PG, Woolf SH, Eccles M, et al. Clinical guidelines: developing guidelines. BMJ 1999; 318: 593-596.

[21] National Guideline Centre (UK). Low back pain and sciatica in over 16s: assessment and management. National Institute for Health and Care Excellence (UK), London, 2016. Available from: https://www.ncbi.nlm.nih.gov/books/NBK401577/ pdf/Bookshelf_NBK401577.pdf [accessed: January 16, 2021].

[22] National Guideline Centre (UK). Low back pain and sciatica in over 16s: assessment and management. National Institute for Health and Care Excellence (UK), London, 2020. Available from: https://www.nice.org.uk/guidance/ng59/resources/ low-back-pain-and-sciatica-in-over-16s-assessment-and-management-pdf-1837521693637 [accessed: January 16, 2021].

[23] Van Wambeke P, Desomer A, Ailliet L, et al. Low back pain and radicular pain: assessment and management. Good Clinical Practice (GCP). Belgian Health Care Knowledge Centre (KCE), Brussels, 2017. KCE Reports 287. D/2017/10.273/36. Available from: https://kce.fgov.be/sites/default/files/atoms/files/ 
KCE_287_Low_back_pain_Report.pdf [accessed: January 16, 2021].

[24] Van Wambeke P, Desomer A, Jonckheer P, et al. The Belgian national guideline on low back pain and radicular pain: key roles for rehabilitation, assessment of rehabilitation potential and the PRM specialist. Eur J Phys Rehabil Med. 2020; 56: 220-227.

[25] Pangarkar SS, Kang DG, Sandbrink F, et al. VA/DoD clinical practice guideline: diagnosis and treatment of low back pain. J Gen Intern Med. 2019; 34: 2620-2629.

[26] Powell C. The Delphi technique: myths and realities. J Adv Nurs. 2003; 41: 376-382.

[27] German Medical Association. National health care guideline for non-specific low back pain. [Bundesärztekammer (BÄK), Kassenärztliche Bundesvereinigung (KBV), Arbeitsgemeinschaft der Wissenschaftlichen Medizinischen Fachgesellschaften (AWMF). Nationale VersorgungsLeitlinie Nicht-spezifischer Kreuzschmerz. Langfassung, 2. Auflage. Version 1. 2017.] DOI: 10.6101/ AZQ/000353. Available from: https://www.leitlinien.de/ $\mathrm{mdb} /$ downloads/nvl/kreuzschmerz/kreuzschmerz-2auflvers1-lang.pdf [accessed: January 16, 2021]. [German]

[28] Chenot JF, Greitemann B, Kladny B, et al. Non-specific low back pain. Dtsch Arztebl Int. 2017; 114: 883-890.

[29] Qaseem A, Wilt TJ, McLean RM, et al. Noninvasive treatments for acute, subacute, and chronic low back pain: a clinical practice guideline from the American College of Physicians. Ann Intern Med. 2017; 166: 514-530.

[30] Scottish Intercollegiate Guidelines Network (SIGN). Management of chronic pain (SIGN publication, No. 136). SIGN, Edinburgh, 2013. Available from: https://www.sign.ac.uk/assets/ sign 136.pdf [accessed: May 4, 2021]

[31] Toward Optimized Practice (TOP) Low Back Pain Working Group. Evidence-informed primary care management of low back pain: clinical practice guideline. AB: Toward Optimized Practice. Edmonton, 2015. Available from: http://www.topalbertadoctors.org/cpgs/885801 [accessed: May 4, 2021].

[32] Finucane LM, Downie A, Mercer C, et al. International framework for red flags for potential serious spinal pathologies. J Orthop Sports Phys Ther. 2020; 50: 350-372.

[33] Simula AS, Ruokolainen O, Oura P, et al. Association of STarT Back Tool and the short form of the Örebro Musculoskeletal Pain Screening Questionnaire with multidimensional risk factors. Sci Rep. 2020; 10: 290

[34] Smith BE, Littlewood C, May S. An update of stabilisation exercises for low back pain: a systematic review with meta-analysis. BMC Musculoskelet Disord. 2014; 15: 416

[35] Horváth G, Koroknai G, Ács B, et al. Prevalence of low back pain and lumbar spine degenerative disorders. Questionnaire survey and clinical-radiological analysis of a representative Hungarian population. Int Orthop. 2010; 34: 1245-1249.

[36] Chou R, Fu R, Carrino JA, et al. Imaging strategies for low-back pain: systematic review and meta-analysis. Lancet 2009; 373: $463-472$.
[37] Webster BS, Choi Y, Bauer AZ, et al. The cascade of medical services and associated longitudinal costs due to nonadherent magnetic resonance imaging for low back pain. Spine 2014; 39: 1433-1440.

[38] Chou D, Samartzis D, Bellabarba C, et al. Degenerative mag netic resonance imaging changes in patients with chronic low back pain. Spine 2011; 36: S43-S53.

[39] Nicholas MK, Linton SJ, Watson PJ, et al. Early identification and management of psychological risk factors ("yellow flags") in patients with low back pain: a reappraisal. Phys Ther. 2011; 91: 737-753.

[40] Traeger A, McAuley JH. STarT Back Screening Tool. J Physiother. 2013; 59: 131 .

[41] Szita J, Kiss L, Biczo A, et al. Outcome of group physical therapy treatment for non-specific low back pain patients can be predicted with the cross-culturally adapted and validated Hungarian version STarT back screening tool. Disabil Rehabil. 2020 Jul 31. [Online ahead of print]

[42] Lin I, Wiles L, Waller R, et al. What does best practice care for musculoskeletal pain look like? Eleven consistent recommendations from high-quality clinical practice guidelines: systematic review. Br J Sports Med. 2020; 54: 79-86.

[43] Geneen LJ, More RA, Clarke C, et al. Physical activity and exercise for chronic pain in adults: an overview of Cochrane Reviews. Cochrane Database Syst Rev. 2017; (4): CD011279.

[44] Owen PJ, Miller CT, Mundell NL, et al. Which specific modes of exercise training are most effective for treating low back pain? Network meta-analysis. Br J Sports Med. 2020; 54: 1279-1287.

[45] Steffens D, Maher CG, Pereira LS, et al. Prevention of low back pain: a systematic review and meta-analysis. JAMA 2016; 176: 199-208.

[46] Illés ST. Low back pain: when and what to do? [A derékfájás: mikor és mit tegyünk?] Orv Hetil. 2015; 156: 1315-1320. [Hungarian]

[47] Machado GC, Maher CG, Ferreira PH, et al. Non-steroidal antiinflammatory drugs for spinal pain: a systematic review and meta-analysis. Ann Rheum Dis. 2017; 76: 1269-1278.

[48] Szekanecz Z. Low back pain - from evidence to clinical practice. [Derékfájás - evindenciáktól a napi gyakorlatig.] Háziorv Továbbképző Szle. 2010; 15: 14-19. [Hungarian]

[49] Eisenbeck N, Schlosser K, Szondy M, et al. Acceptance and Commitment Therapy: theoretical background and practice. [Elfogadás és Elköteleződés Terápia: Elméleti háttér és gyakorlati alkalmazások.] Psychiat Hung. 2016; 31: 239-247. [Hungarian]

[50] Hartvigsen J, Hancock MJ, Kongsted A, et al. What low back pain is and why we need to pay attention. Lancet 2018; 391: $2356-2367$.

(Ádám Szilvia dr., Budapest, Kútvölgyi út 2., 1125 e-mail: adam.szilvia@med.semmelweis-univ.hu)

A cikk a Creative Commons Attribution 4.0 International License (https://creativecommons.org/licenses/by/4.0/) feltételei szerint publikált Open Access közlemény, melynek szellemében a cikk bármilyen médiumban szabadon felhasználható, megosztható és újraközölhetö, feltéve, hogy az eredeti szerzỏ és a közlés helye, illetve a CC License linkje és az esetlegesen végrehajtott módositások feltüntetésre kerülnek. (SID_1) 